\title{
t......
}

\author{
化学反応のレーザー光による量子制御 \\ 川崎 昌博, 杉田明宏 \\ 京都大学 工学研究科 分子工学専攻 (
}

\section{Quantum Control of Chemical Reactions by Laser Light}

\author{
Masahiro KAWASAKI and Akihiro SUGITA \\ Department of Molecular Engineering, Kyoto University, Yoshidahonmachi, Sakyo-ku, Kyoto 606-8501
}

(Received February 12, 1999)

\begin{abstract}
Quantum control of chemical reactions was first proposed by Brumer and Shapiro. Since then, various other ideas have been reported, using quantum mechanical interference and manipulation of wave packets. In this review, recent progress of the quantum control is discussed.
\end{abstract}

Key Words: Coherent control, Phase control, Manipulation, Wave packet

1.はじめに

二十世紀における科学の最大の成果の1つである量子論 が確立されて以来, 分子の量子状態をいかにして観測する か, また, マクロな物質の性質が分子固有の量子状態とど のように関係しているかを解明することに多くの研究 . 努力がなされてきた．その次の発展段階として現在,物質 の量子状態を能動的に操作し, 積極的に物性を変えようと する量子状態の直接操作 [量子制御」がトピックスの一つと して注目を集めている。レーザーによるコヒーレント光 制御技術が進歩して, 「量子制御」の可能性が実現化の様相 を帯びてきたためである.

量子制御の研究は, 1986年にBrumerとShapiro ${ }^{1}$ が, 位相差 をもった $2 つ の$ 光を分子に照射して, 光励起状態からの反応 分岐比を制御する理論を提唱したことから始まる．2年後 には, Elliottら 2)がHg原子について, 続いてGordonら ${ }^{3)}$, Bersohn拈よび川崎ら ${ }^{4)}$ が多原子分子のイオン化断面積に 対する光位相制御の実験結果を報告した。

一方, 1988年にRabitz ${ }^{5)}$, Tannor とRice ${ }^{6)} ら は$ 核波束運動を 反応の終状態の位置に移動させるにはどの様な超短時間 パルス波形をつくればよいかを予測する最適制御理論を 提唱した。これに基づきShank, Wilson ${ }^{7)}$ はチャープパルス による光励起法を用いて, 弚㞦ぞれ色素やヨウ素分子の電 子励起状態に抢ける一定の運動量をもった核波束運動の 制御実験に成功している。 さらに凝縮相分子の反応ダイ ナミックスの例として, 極低温中に抢ける $\mathrm{I}_{2}$ の反応の制御 についても報告がある ${ }^{8)}$. Dantusら ${ }^{9)}$ は $\mathrm{CH}_{2} \mathrm{I}_{2}$ から生じる $\mathrm{I}_{2}$ 分子の解離反応制御を行った. Bandrauk ${ }^{10)}$ は強いレーザー 場中での分子反応制御の理論研究を行い, Corkum书よび酒 井ら 11) がクーロン爆発を利用した核波束運動の実験を報
告した。また, Manzら ${ }^{12)}$ は表面吸着分子の異性化, 解離反 応の非定常レーザー制御理論を構築し, 核波束運動の制御 実験条件を吟味した。

\section{2. 量子制御の原理}

量子制御のうち, Fig.1 (a)-(d)に示す4つの方法が実験の 立場から見て興味深い。

(a) 位相による制御：電子励起状態にある分子が複数の異 なった反応チャンネルに進む時, その光吸収確率ならびに 反応分岐比を $2 つ の$ 異なった光によって制御する。この際 の制御パラメーターは,それぞれの光の持つ位相である. (b) 波束制御による準位分布の移動：波束が出現するダイ ナミックスを制御して,ある特定の励起準位に効率的に移 動させる. パラメーターは, 光遷移の周期 (Rabi周波数) と

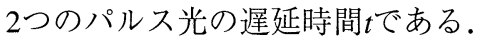

(c) 波束制御による光触媒作用: 強い光によって分子の波 束の動きを, 基底状態 $\rightarrow$ 励起状態 $\rightarrow$ 基底状態と制御するこ とで, 基底状態に存在するポテンシャル障壁を越える反応 を起こす。パラメーターは,強い光の場による分子準位の 広がりである。

(d) 光強電場による反応制御：強い光でポンプされた分子 のポテンシャル曲面(光の衣を着た状態, photodressed state) は, 光強度に依存してその形を変えるので, プローブ光に よって分子の核間距離を制御できる。 パラメーターは, 光 強度とその波長抢よび2つのパルス光の遅延時間である。

まず, Fig.1（a)に示す場合の制御原理について述べる. 分子が光 $\left(\omega_{3}\right)$ を 1 光子吸収するとき,その遷移行列要素は, $\left\langle\Psi_{\mathrm{e}}\left|-\boldsymbol{\mu} \cdot \boldsymbol{E}\left(\omega_{3}\right)\right| \Psi_{0}\right\rangle$ で表わされる。一方, 3つの $\omega_{1}$ 光子が関 与する3光子遷移については, $\left\langle\Psi_{\mathrm{c}}\left|-\boldsymbol{T} \cdot \boldsymbol{E}^{3}\left(\omega_{1}\right)\right| \Psi_{0}\right\rangle$ となる. 
ここで, $\boldsymbol{\mu}$ は1光子遷移双極子オペレーター, $\boldsymbol{T}$ は3光子遷移 双極子オペレーター, そしてEは光の電場ベクトルであ る.したがって,分子がそれぞれの光を個別に光吸収すると き, 1 光子遷移確率は次式で与えられ，

$$
P_{3}=\left|\left\langle\Psi_{\mathrm{e}}\left|-\boldsymbol{\mu} \cdot \boldsymbol{E}\left(\omega_{3}\right)\right| \Psi_{0}\right\rangle\right|^{2}
$$

また, 3 光子遷移確率は次式となる.

$$
P_{1}=\left|\left\langle\Psi_{\mathrm{e}}\left|-\boldsymbol{T} \cdot \boldsymbol{E}^{3}\left(\omega_{1}\right)\right| \Psi_{0}\right\rangle\right|^{2}
$$

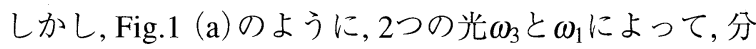
子が同時に励起された場合, 分子の光遷移確率 $P$ はこれら 遷移行列要素の和の 2 乗となるので,干渉項として次式の第 3項が現れる。

$$
\begin{aligned}
P\left(\Delta \phi, \delta_{13}\right) & =\left|\left\langle\Psi_{\mathrm{e}}\left|-\boldsymbol{\mu} \cdot \boldsymbol{E}\left(\omega_{3}\right)\right| \Psi_{0}\right\rangle+\left\langle\Psi_{\mathrm{e}}\left|-\boldsymbol{T} \cdot \boldsymbol{E}^{3}\left(\omega_{1}\right)\right| \Psi_{0}\right\rangle\right|^{2} \\
& =P_{3}+P_{1}+2 \sqrt{P_{1} P_{3}} \cos \left(\Delta \phi+\delta_{13}\right)
\end{aligned}
$$

ここで, $\Delta \phi は \omega_{3}$ と $\omega_{1}$ の相対的な位相差であり, 実験室にお いて変えることができるパラメーターである．したがっ て, 入射光の相対位相 $\Delta \phi$ を任意に変化させることで, 光遷 移確率 $P$ を増減させることが可能となる，右辺第3項中の $\delta_{13}$ は 1 光子 · 3 光子遷移双極子オペレーターの相対的な位 相差である。また, Fig.1（a)において左右の反応チャンネ ルの位相 $\delta_{13}(\mathrm{~L}), \delta_{13}(\mathrm{R})$ の差を $\Delta \delta_{13}$ とおくと, $\Delta \delta_{13}=\delta_{13}(\mathrm{R})$ - $\Delta \delta_{13}(\mathrm{~L}) \neq 0$ である時は $\Delta \phi$ を変えることによって, 左右の 反応チャンネルへの進行を選択できることになる，位相 制御法によって左右の異なる2つの反応分岐比を制御する ためには, 反応チャンネルの位相 $\delta_{13}$ を乱さないために始状 態の位相を単一のものに揃えておくことが必要である13).

上記の制御原理は入射光を定常光としている.しかし， Fig.1 (b)-(d)に示してある分子ダイナミックスの制御では, 時間依存の波動関数を取り扱う必要がある. 時刻 $t=0$ にお いて, 分子とパルス光が瞬間的に相互作用を開始した時, 任 意の時刻 $t$ での分子の状態 $\Psi(t)$ は, 2 状態モデルを用いると 次式のように表される.

$$
\begin{aligned}
& \Psi(t)=\mathrm{c}_{1}(t) \Psi_{1}+\mathrm{c}_{2}(t) \Psi_{2} \\
& \mathrm{c}_{1}(t)=\cos (\Omega t / 2)+\mathrm{i}(\Delta / \Omega) \sin (\Omega t / 2) \\
& \mathrm{c}_{2}(t)=-\left(\Omega_{0} / \Omega\right) \cos (\Omega t / 2) \\
& \Omega=\left[\Omega_{0}^{2}+\Delta^{2}\right]^{1 / 2}
\end{aligned}
$$

ここで $\Omega_{0}$ は共鳴時のラビ佶波数, $\Delta$ は共鳴周波数からUず れである.この式を用いると, 時刻 $t$ における状態 $\Psi_{2}$ の存在 確率 $\left|\mathrm{c}_{2}(t)\right|^{2}$ が(5)式で得られる.

$$
\left|\mathrm{c}_{2}(t)\right|^{2}=(1 / 2)\left(\Omega_{0} / \Omega\right)^{2}[1-\cos (\Omega t)]
$$

これから,ある時刻 $t$ れおける状態 $\Psi_{2}$ の存在確率を制御する ためには, $\Omega_{0}$ と $\Delta$ 大小を変えれば良いことが分かる。こ れが,パルス波形の整形と呼ばれる手法であり, 単一パル ス内で $\Delta$ の值を負 $\rightarrow$ 零 $\rightarrow$ 正と変化させることで, 状態 $\Psi_{2}$ の 反転分布を得ることができる. 強い光の場では, 分子と光 の相互作用を取り込んだ状態(photodressed state)を考えな ければならない。この状態のポテンシャルエネルギーは,

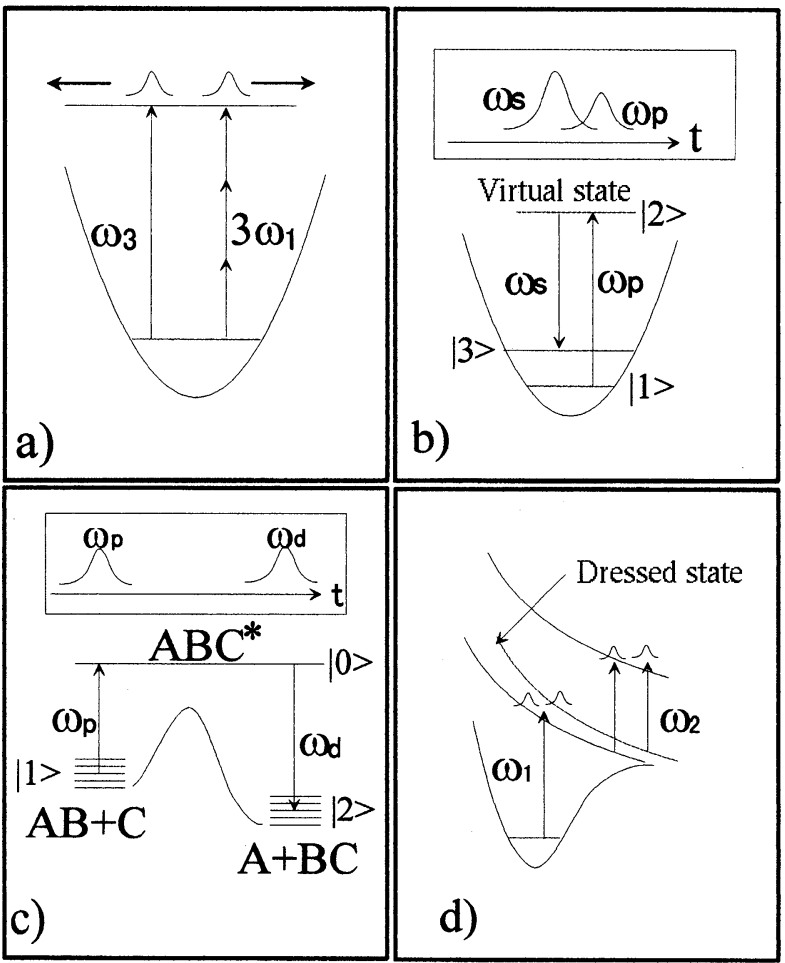

Fig.1 Four different schemes of coherent control. (a) phase control, (b) population inversion, (c) photocatalysis, and (d) photodressed state.

光の強度と周波数により変化する.このように, 分子波束 の動きを制御するコヒーレント分布移動によって,また, 2 つのパルスの遅延時間制御によって, Fig.1 (b)-(d)に示す 反応ダイナミックスの制御や, ある特定の量子準位の反転 分布を実現することが可能となる。この点に関しては藤 村による総説に詳しく述べてある14).

\section{3. 入射光位相による化学反応の制御}

\section{1 光吸収確率の制御}

ナノ秒パルスレーザー装置を用いて分子の光吸収確率

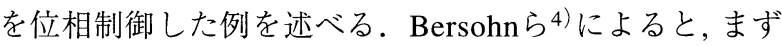
$600.6 \mathrm{~nm}$ のレーザー光を気体媒体により3倍波変換し， 200.2nm光を発生させる.これら2つのレーザー光を,アル ゴンガスセル中を通過させることにより, 可視・紫外レー ザー光の相対的な光位相を変え, その後, 分子に同時に集 光照射与る。分子としてンクロオクタテトラエン $\left(\mathrm{c}-\mathrm{C}_{8} \mathrm{H}_{8}\right)$ を用い, レーザー光が通過するセル中のArガス圧力 $p$ を変 えた時, 光吸収確率にFig.2に示す周期的变化がみられた。 これは, (3)式に現れるレーザー光位相差 $\Delta \phi か ゙$ 変化したか らである。

また, Fig.2に現れる周期的変化に対応して, (3)式のPの 最大值と最小値を用いて, 制御能を示す量 $F$ を定義する.

$$
F=\left(P_{\text {max }}-P_{\text {min }}\right) /\left(P_{\text {max }}+P_{\text {min }}\right)=2 \sqrt{P_{1} P_{3}} /\left(P_{1}+P_{3}\right)
$$

この $F$ は $P_{1}=P_{3}$ の時に最大となる。つまり，位相制御をよ り選択的にするためには, 1 光子遷移確率 $P_{3}$ と 3 光子遷移確 率 $P_{1}$ が同じになるように, 可視・紫外レーザー光強度なら 


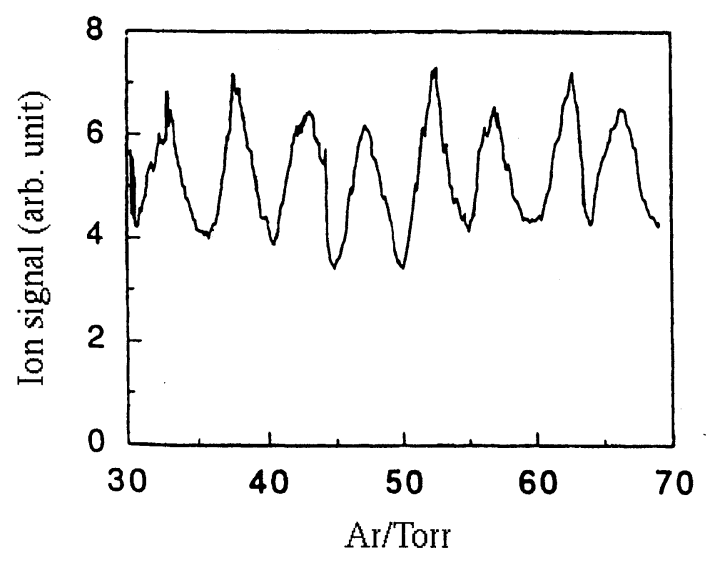

Fig.2 Phase control of the photoabsorption of cyclooctatetraene by the phase lag between 201 and 603 nm laser light. ${ }^{4 b)}$

びにそれらの空間的重なりを調節する必要がある.

光吸収確率の位相制御実験が容易な試料として, $\mathrm{Kr}$, $\mathrm{X} \mathrm{e}^{15)}$ などの原子や, $\mathrm{NO}, \mathrm{CO}$ な゙の簡単な分子があげられ る. しかし, ヨウ化メチル,アンモニア,トリメチルアミン, $\mathrm{c}-\mathrm{C}_{8} \mathrm{H}_{8}$ のような一般の無機・有機分子でも光吸収確率の位 相制御は可能である ${ }^{4)}$. Fig.1 (a)の光励起過程と異なり,2 光子・4光子励起による場合にも, 終状態が同じ対称性であ れば光吸収断面積の制御は可能となる16).

\section{2 反応経路の位相制御}

Fig.1（a）に示すような反応経路制御の例としては, Gor-

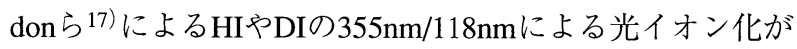
ある。

$$
\begin{aligned}
\mathrm{DI}+355 \mathrm{~nm} / 118 \mathrm{~nm} & \rightarrow \mathrm{DI}^{+} \\
& \rightarrow \mathrm{D}+\mathrm{I}^{+}
\end{aligned}
$$

$\mathrm{DI}^{+}$と $\mathrm{I}^{+}$の信号強度は入射レーザー光の相対位相 $\Delta \phi に$ 対し て, (3) 式で示す余弦関数の依存性を持つ. 加えて, それぞ れのチャンネルの位相差, $\delta_{13}\left(\mathrm{DI}^{+}\right)-\delta_{13}\left(\mathrm{I}^{+}\right)=\Delta \delta_{13}$ も信号 強度に影響する. Lee ${ }^{18)}$ のモデル計算によると $\Delta \delta_{13}$ の大小 は3光子遷移双極子オペレーターに依存して扔り,もし中間 状態として実状態を経由する3光子過程であれば $\Delta \delta_{13} \approx 0$ と なる. 実際にGordonら 17)の実験結果にはこの共鳴効果が 現れ, $\Delta \delta_{13}$ は2光子共鳴のある3光子吸収の波長 $353.9 \mathrm{~nm}$ で零 に近づいている。したがって, 共鳴準位を避けて, $\delta_{13}$ が大 きい波長を選ぶことにより反応の位相制御が可能とな る.

反応チャンネル固有の位相 $\delta_{13}$ に関連して終状態が解離 状態, 光イオン化状態を考える.もし, 多数の異なった位 相をもつ始状態が光励起された時には, 位相成分 $\delta_{13}$ が平均

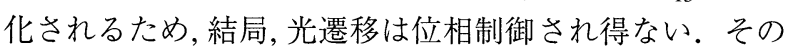
ため,極低温に分子を泠却しておくことが実験的には必要 とされている. しかし, Gordonら ${ }^{19)} の \mathrm{H}_{2} \mathrm{~S}$ の光イオン化実 験結果に扔いては,チャンネル位相 $\delta_{13}$ は回転準位には無関 係である.また, 安定状態の波動関数は実関数であり,そ の 1 光子 · 3 光子遷移双極子オペレーターの位相は $\delta_{13}=0$ (または $\pi$ )のみとなるので, 室温にある有機分子の安定状態
間の光遷移は位相制御可能となる4).

3.3 光解離生成物の空間角度分布の位相制御

分子が光を吸収して分解する時, 光分解生成物は空間角 度分布を持つ. 分子の光吸収は, (1)式のように光の電場方 向と分子の遷移双極子モーメントの内積で表される。そ の結果, 直線偏光を用いれば, 生成する解離生成物は偏光 方向に空間角度分布を示す。この空間角度分布を実験的 に調べる方法として画像分光法がある20)。この方法では, 親分子の光吸収により生成した解離生成物をイオン化さ せ加速電極で蛍光スクリーン方向にはじき飛ばす．イオ ンが蛍光スクリーンにぶつかると蛍光を発し，その蛍光を 2次元検出器であるCCDカメラで観測する．観測した画像 を見れば, 偏光に対し角度 $\theta$ に散乱した角度・速度分布が わかる. 分子が光子 1 個を吸収し光分解するとき, その光遷 移確率は, (1) 式の 1 光子遷移モーメント, $\boldsymbol{\mu E}=\mu E \cos \theta$ の 2 乗で与えられ, 光吸收微分断面積はこれに比例する。した がって, 空間的に等方的に分布する分子を直線偏光で光分 解するとき, 解離生成物の角度分布は (8) 式となる。

$$
S_{1}(\theta)=\mu^{2} E^{2}\left(\omega_{2}\right) \cos ^{2} \theta
$$

例として, $\mathrm{CH}_{3} \mathrm{I}$ の紫外1光子解離で生成する原子の角度分 布測定結果をFig.3（a)に示す.

さて, Bersohnら 21) はFig.1 (a)の2ビーム法を用い, 1光子 . 2 光子遷移間の位相を変えることにより,この解離生成物の 空間角度分布を制御できることを理論的に示した. 分子 が 2 光子吸収して分解するとき, 中間状態 $\Psi_{\mathrm{n}}$ の遷移が平行 のみの場合を考えると, 2 光子遷移確率は (9)式に比例す る.

$$
\begin{aligned}
& \left\langle\Psi_{\mathrm{e}}\left|-\mu_{\mathrm{en}} \cdot \boldsymbol{E}\left(\omega_{1}\right)\right| \Psi_{\mathrm{n}}\right\rangle\left\langle\Psi_{\mathrm{n}}\left|-\mu_{\mathrm{n} 0} \cdot \boldsymbol{E}^{2}\left(\omega_{1}\right)\right| \Psi_{0}\right\rangle \\
& =E^{2}\left(\omega_{1}\right) \cos ^{2} \theta
\end{aligned}
$$

2 光子吸収の微分断面積 $S_{2}(\theta)$ は, この式の 2 乗に比例するか ら, 解離生成物の角度分布は次式となる。

$$
S_{2}(\theta)=B^{2} E^{4}\left(\omega_{1}\right) \cos ^{4} \theta
$$

ここでBは吸収断面積を含む係数である。次に(3)式にお いて議論したと同様に, $2 つ の$ 異なった光 $\omega_{1}$ と $\omega_{2}$ が同時に 分子に作用すれば,この時の光吸収微分断面積には干渉項 が現れる．最も大きい変化を示すのは, 1 光子遷移確率と 2 光子遷移確率が同じ時である。 (9), $(10)$ 式において $E^{2}\left(\omega_{1}\right)$ $=B^{2} E^{4}$ と㧍いた時, 微分断面積つまり光解離生成物の角度 分布は次式に比例する。

$$
S(\theta)=\cos ^{2} \theta+\cos ^{4} \theta-2 \cos ^{3} \theta \cos (\Delta \phi)
$$

ここで, $\Delta \phi$ はつの光, $\omega_{1}$ と $\omega_{2}$ の位相差である。 これを積分 すればわかるが, 全断面積には干渉効果は見られない.

(11)式に扔いて $\Delta \phi=\pi / 4$ とした時, その角度分布変化はFig. 3 （b）となる．また光遷移が垂直遷移である2原子分子では Fig. 3 (c) となる. しかし非直線 3 原子分子, $\mathrm{H}_{2} \mathrm{O}$ (結合角 $=$ $\left.52.5^{\circ}\right)$ ではほとんど変化がみられない.この結果, 平行遷 移である2原子分子を用いれば,顕著な位相制御が実験的に 可能であると予想される. 


\section{Laser polarization}
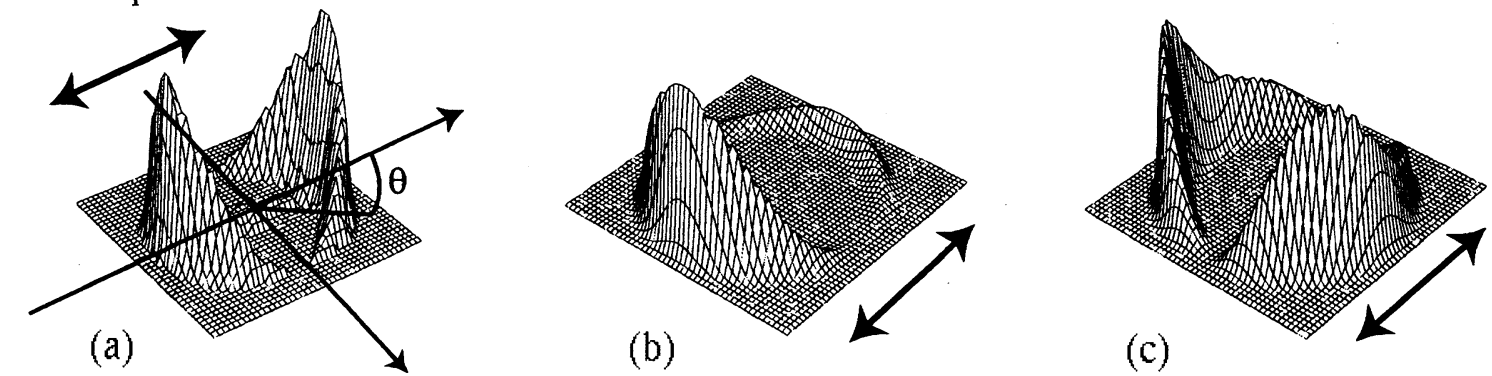

Fig.3 Phase control of angular distribution: (a) Experimental angular distribution of I atom photofragments from the $\mathrm{CH}_{3} \mathrm{I}$ photodissociation at $304 \mathrm{~nm}$. (b) Calculated angular distribution from Eq.(11), with $\Delta \phi=\pi / 4$, assuming two consecutive parallel transitions. (c) Calculated angular distribution, with $\Delta \phi=\pi / 4$, assuming two consecutive perpendicular transitions.

非常に強いレーザー場による「光の衣を着た分子」を用 いて $\mathrm{Kr}^{22)}, \mathrm{Rb}^{23)}, \mathrm{NO}^{24)}$ の光電子の角度分布制御が,この1光 子・2光子法で行われている. しかしながら解離生成分子 の角度分布制御の直接観測は未だなされていない。

\section{4. 核波束の運動制御による反応の制御}

\section{1 分布移動の制御}

光と分子の相互作用は瞬発的ではなく,ある時間をかけ て働く，従ってダイナミックスを記述するには, 時間に依 存するSchrödinger方程式を解く必要がある。その時, (4), (5)式に現れるラビ周波数, 共鳴周波数のずれは時間の関数 となり, $\Omega(t), \Omega_{0}(t), \Delta(t)$ として表される. 存在確率には これらのパラメーターが含まれているので,これらパラ メーターの時間変化を制御することにより，反応を制御す ることが出来る。これらのパラメーターをゆっくりと変 化させ断熱状態を経由することによって制御を実現する方 法を断熱通過という. Fig.1 (b)に示したような誘導ラマン 断熱通過を利用して状態 $|1\rangle$ から $|3\rangle$ への分布移動が制御で き,これは断熱通過による分布反転と呼ばれている. 誘導 ラマン断熱通過は, ポンプ光ーストークス光パルス間の時 間差を操作することによって分布移動を制御する方法で ある. まずダンプ光としてストークス光 $\omega_{\mathrm{s}}$ を入射し仮想状

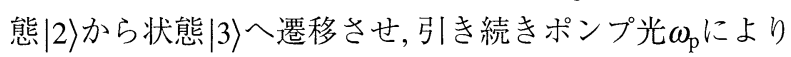
状態 $|1\rangle$ から仮想状態 $|2\rangle$ 个遷移させることで最終的には状 態|3〉の反転分布を得る. 実際にNa 2 について効率的な分布 移動をBergmannが行った25).

また別の方法としてチャープパルス(周波数を掃引した パルス）を利用した制御法がある。線形チャープパルスは $\omega(t)=\omega+\xi t$ で表され, 分子との相互作用に対してラビ周 波数, 共鳴周波数のずれ $\Omega(t), \Omega_{0}(t), \Delta(t)$ が時間変化し, 分 布移動の制御が出来る。実際にチャープパルスを利用し て,2準位モデル系でMellingerら 26)がp-terphenylに埋め込ま れたpentaceneの ${ }^{1} \mathrm{~B}_{2 u} \leftarrow{ }^{1} \mathrm{~A}_{1 \mathrm{~g}}(0-0)$ 振動電子遷移の制御を試み ている. 彼らは多準位系である気相 $\mathrm{I}_{2}$ の $(\mathrm{B} \leftarrow \mathrm{X})$ 遷移に対 しても応用に成功している. Dantusら ${ }^{9}$ はチャープパルス による $\mathrm{CH}_{2} \mathrm{I}_{2}$ 分子から生じた $\mathrm{I}_{2}$ 分子の解離生成量の制御を 報告している。また山下ら 27) は超極短パルス領域の チャープパルスを用いた非断熱遷移の理論的研究を行い, $\mathrm{O}_{2}$ 分子, $\mathrm{CO}$ 分子への実験的応用を示唆した.

\section{2 光触媒作用}

Fig.1 (c)に示したようにポンプーダンプ法を用いて波束 の運動を制御することにより, ポテンシャル障壁を越える ことが出来る. まず $\mathrm{AB}+\mathrm{C} か ゙$ 状態 $|1\rangle$ に対応し,これらが ポテンシャル障壁を越えて反応し, AとBCになった時を状 態 $|2\rangle$ とする。 $|1\rangle$ 状態にある $\mathrm{AB}$ とCが衝突する際, ポンプ 光 $\omega_{\mathrm{p}}$ により $\mathrm{ABC}$ 分子の混合状態 $|0\rangle$ 遷移させる.ポンプ 光 $\omega_{\mathrm{p}}$ と衝突による断熱状態 $|0\rangle$ は $\mathrm{ABC} *$ という $\mathrm{AB}$ と $\mathrm{C}$ が一体 となった状態である.ポンプ光 $\omega_{\mathrm{p}}$ の通過後, ダンプ光 $\omega_{\mathrm{d}}$ が 通過し相互作用が終わると, 分布は $|2\rangle$ へ移動する.すなわ ちA+BCとなり，ポテンシャル障壁を越えた結果となる。

$$
\begin{aligned}
& \mathrm{AB}+\mathrm{C} \stackrel{\hbar \omega_{\mathrm{p}}}{\longrightarrow} \mathrm{AB} *+\mathrm{C} \stackrel{\text { collision }}{\longrightarrow} \\
& \mathrm{ABC} * \stackrel{\hbar \omega_{\mathrm{d}}}{\longrightarrow} \mathrm{ABC} * * \longrightarrow \mathrm{A}+\mathrm{BC}
\end{aligned}
$$

Zhuら ${ }^{28)}$ はこの原理に基づき, コヒーレント光による光 触媒作用を行った。励起したXeから基底状態にある $\mathrm{Kr} へ$ のエネルギー移動である。彼らが行ったポンプープロー ブ法をFig.4に示した. $2 \omega_{1}$ によって励起したXe*とKrが衝

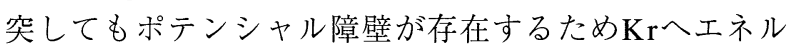
ギー移動は生じない. しかし, 光励起と衝突によって

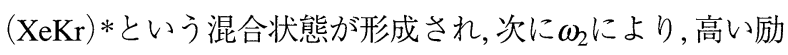
起状態 $(\mathrm{XeKr})$ **へ遷移させてみたところ, Xeと Kr*が生成 した。すなわち，的によってエネルギー移動した結果とな る.

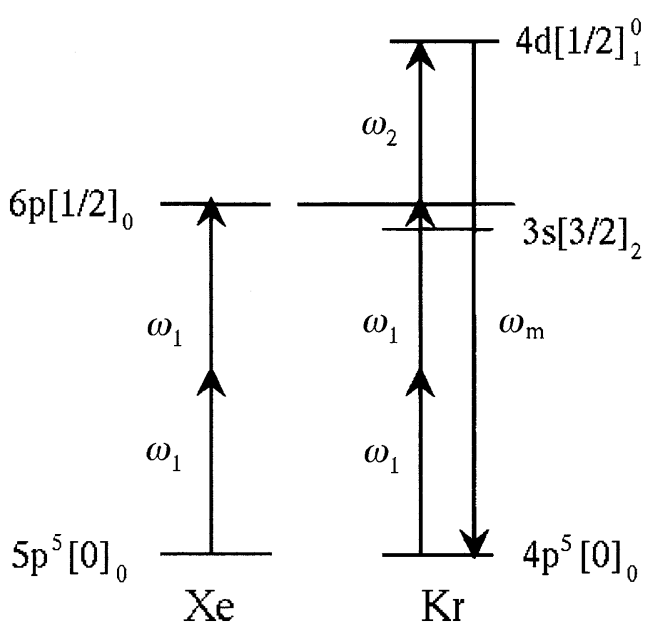

Fig.4 Laser catalysis of energy transfer between Xe* and $\mathrm{Kr}^{29)}$ 


$$
\begin{aligned}
& \mathrm{Xe}+\mathrm{Kr} \stackrel{\hbar\left(2 \omega_{1}\right)}{\longrightarrow} \mathrm{Xe} *+\mathrm{Kr} \stackrel{\text { collision }}{\longrightarrow} \\
& \mathrm{XeKr} * \stackrel{\hbar \omega_{2}}{\longrightarrow} \mathrm{XeKr} * * \stackrel{\text { repulsion }}{\longrightarrow} \mathrm{Xe}+\mathrm{Kr} *
\end{aligned}
$$

4.3 ポテンシャル曲面の制御による化学反応の制御 強い光子場によって生成する「光子の衣を着た状態」は 相互作用の大きさにより,そのポテンシャル曲面を変化さ せる. Chenら ${ }^{29)}$ はレーザー強度を変えることによる $\mathrm{OClO}$ 分子の解離過程の制御を報告している。 $\mathrm{OClO}$ 分子には光 吸収により次の2つの解離過程が存在する。

$$
\begin{aligned}
\mathrm{OClO}+h v & \longrightarrow \mathrm{OClO} *\left({ }^{2} \mathrm{~A}_{2}\right) \rightarrow \mathrm{O}+\mathrm{ClO} \\
& \mapsto \mathrm{OClO} *\left({ }^{2} \mathrm{~A}_{2},{ }^{2} \mathrm{~B}_{2}\right) \rightarrow \mathrm{Cl}+\mathrm{O}_{2}
\end{aligned}
$$

考えているエネルギー領域には ${ }^{2} \mathrm{~A}_{2},{ }^{2} \mathrm{~A}_{1},{ }^{2} \mathrm{~B}_{2}$ の3つのOClO* の励起状態があるが, レーザー場が弱い時には ${ }^{2} \mathrm{~A}_{2}$ への励起 がほとんどである。この時, (12)式の過程はポンプ光レー ザー強度を大きくすると ${ }^{2} \mathrm{~A}_{2}$ への励起は飽和し, $\mathrm{ClO}$ の生成 量もやがて減少し始める. 一方, ポンプ光レーザー強度を 大きくすると励起状態OClO*のポテンシャル曲面が変化 し, ${ }^{2} \mathrm{~A}_{1},{ }^{2} \mathrm{~B}_{2}$ への遷移確率が増大する。その結果, (13)式の 分解過程が有効に起こり, $\mathrm{O}_{2}$ の生成量はポンプ光強度に比 例して増大していく．このようにポンプ光レーザー強度 の変化により反応の分岐比を制御している.

「光の衣を着た」分子について, Corkum ${ }^{11)}$ はクーロン爆発 を利用してFig.1 (d)に示したような $\mathrm{I}_{2}$ 分子の核波束運動の 制御実験を行っている。またSheerhy ${ }^{30)} ら は H^{+} \rightarrow \mathrm{H}^{+}+\mathrm{D} / \mathrm{H}$ $+\mathrm{D}^{+}$の分岐比制御を報告している.

\section{参考文献}

1) (a) M. Shapiro and P. Brumer: Chem. Phys. Lett. 126 (1986) 541.; (b) J. Chem. Soc. Faraday Trans. 93 (1997) 1263.

2) (a) C. E. Chen, Y.-Y. Yin, and D. S. Elliott: Phys. Rev. Lett. 64 (1990) 507.; (b) C. E. Chen and D. S. Elliott: Phys. Rev. Lett. 65 (1990) 1737

3) S. M. Park, S.-P. Lu, and R. J. Gordon: J. Chem. Phys. 94 (1991) 8622

4) (a) G. Xing, X. Wang, X. Huang, R. Bersohn, and B. Katz: J. Chem Phys. 104 (1996) 826.; (b) X. Wang, R. Bersohn, K. Takahashi, M. Kawasaki, and H. L. Kim: J. Chem. Phys. 105 (1996) 2992.

5) (a) A. P. Peirce, M. A. Dahleh, and H. Rabitz: Phys. Rev. A 37 (1988) 4950.; (b) ibid. 42 (1990) 1065.; (c) S. Shi, A. Woody, and H. Rabitz: J. Chem. Phys. 88 (1988) 6870.

6) D. J. Tannor and S. A. Rice: J. Chem. Phys. 83 (1985) 5013.

7) (a) G. Cerullo, C. J. Bardeen, Q. Wang, and C. V. Shank: Chem. Phys. Lett. 262 (1996) 362.; (b) B. Kohler, V. V. Yakovlev, J. Che, J. L. Krause, M. Messina, K. R. Wilson, N. Schwentner, and Y. Yan: Phys. Rev. lett. 74 (1995) 3360.; (c) C. J. Bardeen, J. Che, K. R. Wilson, V. V. Yakovlev, P. Cong, B. Kohler, J. L. Krause, and M. Messina: J. Phys. Chem. A101 (1997) 3815.; (d) V. V. Yakovlev, C. J. Bardeen, J. Che, J. Cao, and K. R. Wilson: J. Chem. Phys. 108 (1998) 2309.

8) C. J. Bardeen, J. Che, K. R. Wilson, V. V. Yakovlev, V. A. Apkarian, C. C. Martens, R. Zadoyan, B. Kohler, and M. Messian: J. Chem. Phys. 106 (1998) 8486.

9) I. Pastrik, E. J. Brown, Q. Zhang, and M. Dantus: J. Chem. Phys. 108 (1998) 4375.

10) A. D. Bandrauk (ed.): Atomic and Molecular processes with short intense laser pulse (Plenum Press, New York, 1987).

11) H. Stapelfeldt, H. Sakai, E. Constant, and P. B. Corkum: Phys. Rev. A 55 (1997) R3319.

12) M. V. Korolkov, J. Manz, and G. K. Paramonov: J. Chem. Phys. 105 (1996) 10874.

13) 中島 隆, 川崎 昌博 : 分光研究 48 (1999) 5.

14）藤村 勇一：分光研究 47 (1998) 141.

15) N. E. Karapanagioti, D. Xenakis, D. Charalambidis, and C. Fotakis: J. Phys. B 29 (1996) 3599.

16) A. D. Bandrauk, J.-M. Gauthier, and J. M. McCann: Chem. Phys. Lett. 200 (1992) 399.

17) (a) L-C. Zhu, V. D. Kleiman, X. Li, S.-P. Lu, K. Trentelman, and R. J. Gordon: Science 270 (1995) 77.; (b) L.-C. Zhu, K. Suto, J. A. Fiss, R. Wada, T. Seideman, and R. J. Gordon: Phys. Rev. Lett. 79 (1997) 4108.

18) S.-G. Lee: J. Chem. Phys. 108 (1998) 3903.

19) V. D. Kleiman, L.-C. Zhu, X. Li, and R. J. Gordon: J. Chem. Phys. 102 (1995) 5863.

20) 鈴木 俊法：分光研究 45 (1996) 3.

21) H. L. Kim and R. Bersohn: J. Chem. Phys. 107 (1997) 4546.

22) H. G. Muller, P. H. Bucksbaum, D. W. Schumacher, and A. Zavriyev: J. Phys. B 23. (1990) 2761.

23) Y.-Y. Yin, C. E. Chen, D. S. Elliott, and A. V. Smith: Phys. Rev. Lett. 65 (1992) 1734.

24) Y.-Y. Yin, D. S. Elliot, R. Shehadeh, and E. R. Grant: Chem. Phys. Lett. 241 (1995) 591.

25) U. Gabatz, P. Rudecki, S. Schiemann, and K. Bergmann: J. Chem. Phys. 92 (1990) 5363.

26) (a) J. S. Mellinger, S. R. Gardhi, and W. S. Warren: J. Chem. Phys. 95 (1991) 2210.; (b) J. S. Mellinger, S. R. Gardhi, A. Hariharan, D. Goswami, and W. S. Warren: J. Chem. Phys. 101 (1994) 6439.

27) K. Mishima and K. Yamashita: J. Chem. Phys. 109 (1998) 1801.

28) W. R. Garett and Y. Zhu: J. Chem. Phys. 106 (1997) 2045.

29) M. Blachwell, P. Ludowaise, and Y. Chen: J. Chem. Phys. 107 (1997) 283.

30) B. Sheerhy, B. Walker, and L. F. DiMauro: Phys. Rev. Lett. 74 (1995) 4799.
量子制御 ·位相制御 (quantum and coherent control)

原子・分子と光のコヒーレントな相互作用に着目し, 原 子・分子のミクロスコピックな状態である非定常単一量 子状態, あるいは, その線形結合状態を取り出し,このコ ヒーレント状態にある原子・分子のポテンシャル曲面で のダイナミックスを光により直接制御することを「量子制 御」と言う。その中でも,特に光の位相を利用して量子制御 することを「位相制御」と言う。最近のレーザー技術の進
歩によって, 光位相ならびに光パルス成形(チャーピング) 技法が発達し, 原子・分子の量子状態を能動的に制御する ことが可能となった。レーザー光による量子制御・位相 制御の例として, 光吸収断面積の制御, 状態分布の移動制 御, 光量子の触媒作用, 化学反応経路 - 反応分岐比の選択, 光電子の角度分布制御などがある。 